\title{
O CORDÃO DA BICHARADA: A PARTICIPAÇÃO DE CRIANÇAS NA BRINCADEIRA DE RUA NO CARNAVAL DE JUABA-CAMETÁ/PA
}

\author{
Ivone Maria Xavier de Amorim Almeida ${ }^{\mathrm{I}}$ \\ Elizete Tenório Valente ${ }^{2}$
}

RESUMO: Este artigo é resultante das coletas de dados realizadas na localidade de Juaba, na cidade de Cametá no período de 2018-2019, vinculadas ao projeto "Festas, Brincadeiras, cortejos, procissões e Atos Devocionais: estudos sobre manifestações populares na amazônia paraense", cujo objetivo se centra na investigação da participação de crianças no cordão da bicharada no carnaval de Juaba. O Cordão da Bicharada é considerado um bloco carnavalesco que homenageia a fauna da Amazônia através do uso de fantasias confeccionadas pelos moradores locais. A apresentação do cordão da bicharada é marcada pelo entusiasmo e alegria dos participantes - adultos e crianças - e com uma visualização estética totalmente peculiar. Toda a fundamentação teórica utilizada na construção dos argumentos reflexivos sobre o tema advém da etnocenologia, acionando as categorias conceituais espetacularidade e teatralidade como mote na compreensão da participação dos integrantes - em especial, as crianças - no cordão da bicharada.

Palavras-chave: cordão da bicharada. Criança. Espetacularidade. teatralidade.

ABSTRACT: This article is the result of data collection sums carried out in the city of Juaba, in the city of Cametá in the period 2018-2019, linked to the project "Parties, Games, processions, processions and Devotional Acts: studies on popular manifestations in the Amazon of Pará", whose objective focuses on the investigation of the participation of children in the cordon of the bicharada in the juaba carnival. Cordão da Bicharada is considered a carnival block that honors the fauna of the Amazon through the use of costumes made by local residents. The presentation of the bicharada cord is marked by the enthusiasm and joy of the participants - adults and children - and with a totally peculiar aesthetic visualization. All the theoretical

\footnotetext{
${ }^{\text {I }}$ Doutora em História Social pela Pontifícia Universidade Católica de São Paulo (2010) e Mestre em Antropologia Social pela Universidade Federal do Pará (1998). É professora Adjunta da Universidade Federal do Pará (UFPA), lotada no Instituto de Ciências das Artes (ICA), vinculada à Escola de Teatro e Dança (ETDUFPA). Compõe o quadro de professores do Programa de Pós-Graduação em Artes em Rede Nacional (UFPA) e do Programa de PósGraduação em Artes (Mestrado e Doutorado) PPGARTES-UFPA, vinculada à linha 2 - Artes e Interfaces Epistêmicas. Coordena projeto de Pesquisa "Festas, Brincadeiras, Cortejos, Procissões e Atos Devocionais: Estudos sobre Manifestações populares na Amazônia" (Portaria I69/2018-ICA). Integra o grupo de pesquisa TAMBOR (Ppgartes-UFPA), coordenado pelo prof. Dr. Miguel de Santa Brígida. Foi coordenadora do curso de Licenciatura em Teatro-UFPA nos períodos 2017/2018 e 2019/2020. Atualmente exerce a função de Vice-Diretora da Escola de Teatro e Dança da UFPA-ETDUFPA. Endereço eletrônico: ivmaxavier@gmail.com /ivone@ufpa.br.

${ }^{2}$ Licenciada em Teatro pela Universidade Federal do Pará - PARFOR-UFPA (2019). Licenciada em Pedagogia pelo Centro Universitário Leonardo da Vinci UNIASSELVI (2015). É professora de Artes na Escola Municipal de Ensino Fundamental Jadielson de Souza Moraes, na localidade do Rio Pacovatuba, Cametá-Pa. Integrou o grupo de pesquisa do projeto Festas, Festas, Brincadeiras, Cortejos, Procissões e Atos Devocionais: Estudos sobre Manifestações populares na Amazônia, coordenado pela prof ${ }^{a}$ Dra. Ivone Maria Xavier de Amorim Almeida, no período de 2018-2019. Endereço eletrônico: elizetevalente@hotmail.com.
} 
foundation used in the construction of reflexive arguments on the theme comes from ethnocenology, triggering the conceptual categories spectacularity and theatricality as a motto in the understanding of the participation of the members - especially children

- in the cord of bicharada.

Keywords: Bichaarada cord. Child. Spectacularity. thetricality

\section{I À GUISA DE UMA INTRODUÇÃO}

O município de Cametá é o mais antigo e tradicional dos baixos rios do Tocantins, pela sua importância histórica empresta seu nome à antiga microrregião de Cametá. Com uma história interessante, Cametá passou à categoria de Patrimônio Histórico Nacional pela lei no ${ }^{\circ}$ 7537, de 16 de setembro de 1986 pela sua notável tradição histórica.

A cidade de Cametá é considerada uma das municipalidades mais antigas do Estado do Pará. Sendo instituída em I62o, pelo Frade Capuchinho Cristóvão José, à margem esquerda do rio Tocantins, onde habitavam os índios Camutás que moravam em casas nos topos das árvores, a cidade Cametaense também recebe uma definição em Tupi como "degrau do mato".

Atualmente Cametá possui ıo distritos, a saber: Distrito-sede, Juanacoeli, Curuçambaba, Carapajó, Moiraba, Vila do Carmo do Tocantins, Areião, Juaba, Torres de Cupijó e Porto Grande. Esses distritos historicamente trazem importantes contribuições econômicas e Culturais à região tocantina.

A comunidade de Juaba, ascendeu a condição de vila distrital através da Lei no I530 de os de outubro de I916. Como Vila Distrital, Juaba comporta um conjunto de comunidades quilombolas, formado pelo quilombo do Mola, Porto Alegre, Laguinho e Tomázia.

De acordo com Gomes (2006), o Distrito do Juaba apresenta extrema importância para Cametá através da produção de farinha e de outros derivados oriundos do plantio da mandioca, cuja logística é realizada pelos próprios ribeirinhos, que agenciam o beneficiamento comercial da farinha para o município tocantino. Toda produção das comunidades quilombolas é comercializada no próprio Distrito ou Vila do Juaba, que nessa perspectiva recebem compradores das regiões próximas e, sobretudo de Cametá. 
A importância do Rio Tocantins no município de Cametá e, particularmente na vila distrital de Juaba, é enfatizada pela ligação que essas localidades mantêm com inúmeros furos, além dos igarapés e braços de rios, que se interpenetram nas dezenas de ilhas que compõem povoados e aglomerações relativamente habitados.

O Município de Cametá - assim como toda região tocantina - é rico em manifestações populares, como as festas de devoção a santos do catolicismo popular, festas juninas e também as de carnaval. Aliás, o carnaval de Cametá é conhecido nos sites de turismo como o "carnaval das águas”, expressão usual que marca a circulação, na região das ilhas, de embarcações com brincantes e foliões caracterizados de bichos da fauna local e de tantos outros que compõem o imaginário fantástico da Amazônia paraense. Mas é importante considerar que o carnaval em Cametá não se restringe à estética do carnaval das águas. É frequente o desfile das escolas de samba, os bailes à fantasia nos clubes locais e os grupos de Fofós que, no período de momo, se concentram na praça da Cultura para a batalha da maizena.

Também na vila de Juaba existe o carnaval do "Cordão da Bicharada" - bloco carnavalesco que homenageia os animais da Amazônia - simbolicamente representados pelos personagens de animais, com participações de moradores locais adultos e crianças. $\mathrm{O}$ colorido das fantasias, o ato performático desenvolvido pelo corpo-brincante e a alegria contagiante gera uma visualização estética capaz de agradar aqueles que assistem a evolução do cordão da bicharada na condição de expectadores.

A estrutura organizativa deste artigo parte de uma reflexão epistemológica na área da etnocenologia para descrever o cortejo do cordão da bicharada e seus elementos estéticos no campo conceitual da teatralidade e espetacularidade. Ao lado destas questões, o artigo também procura revelar a participação das crianças como brincantes do cortejo.

\section{O CORDÃO DA BICHARADA EM JUABA}

O Cordão da Bicharada do Juaba, segundo seu precursor e idealizador, mestre Zenóbio Ferreira ${ }^{3}$, têm sua origem no seu imaginário infantil, quando ouvia histórias

\footnotetext{
${ }^{3}$ Natural de Cametá, 73 anos.
} 
que seu pai, Raimundo Inácio Ferreira (seu Mimico), lhe contava sobre os animais e o meio ambiente onde viviam. Também se inspirou nos livros que leu em sua infância, particularmente, de uma frase lida em um desses antigos livros e nunca esqueceu. Sobre essa memória, seu Zenóbio diz:

Estava lendo um livro, no qual tinha uma frase que me chamou bastante atenção que dizia assim: 'as aves não tem onde pousar'[...] Passou vários anos, encontrei um livro na biblioteca por nome Mundo Animal que tinha várias figuras de animais. Era animal de tudo que era canto. Foi daí que surgiu a ideia de construir as vestimentas dos animais (Mestre Zenóbio. Entrevista concedida em ro de março de 2019, Juaba-Pa).

Durante a entrevista, mestre Zenóbio deixou transparecer sua enorme preocupação, já na década de setenta do século vinte, com o meio ambiente, sobretudo em decorrência das constantes depredações observadas por ele nas regiões das ilhas e na área continental, provocadas por constantes queimadas e desmatamentos. Essa preocupação o levou a "matutar" sobre fazer alguma coisa para alertar o pedido de socorro emitido pela natureza. Foi aí que teve a ideia de criar o cordão da bicharada.

[...] eu queria trazer uma mensagem da floresta para as pessoas, mostrando as dificuldades dos animais com a devastação das matas, com a poluição ambiental e como eles sobrevivem (Mestre Zenóbio. Entrevista concedida em ro de março de 2019, Juaba-Pa).

Com o passar do tempo e diversas apresentações durante vários carnavais, o fundador do cordão acredita que a união entre o homem e natureza foi alcançada. No começo, ele conta que o público ainda se assustava bastante com os animais gigantes que invadiam a cidade para animar a população. Atualmente, segundo ele, é tudo bastante diferente.

Hoje em dia, aonde quer que a gente se apresente, é uma felicidade. Crianças, jovens, adultos e idosos se unem aos bichos. As pessoas tinham medo da gente. Nós tínhamos uma regra de não tirar as máscara e fantasias após o desfile porque queríamos conquistar o povo como bicho e não como gente (Mestre Zenóbio. Entrevista concedida em ro de março de 2019, Juaba$\mathrm{Pa})$.

A Bicharada do Juaba é definida por seu fundador como cordão carnavalesco. No Nôvo Diccionário da Língua Portuguêsa, de Candido de Figueiredo, publicado em 1889, há várias definições para a palavra cordão, mas como era de esperar, não há uma definição sobre cordão compreendido como grupo ou manifestação carnavalesca. 
Figueiredo define cordão como: "corda delgada; fileira; série de postos militares para evitar contágio; objecto ou orgam, que tem semelhança com uma pequena corda" (FIGUEIREDO, I889, p. 347). Já a versão atualizada do Novo

Diccionário da Língua Portuguesa (FIGUEIREDO, 1913), além das definições da versão anterior, aparece também a palavra cordão como manifestação ou grupo carnavalesco. Nesse sentido, a definição de Figueiredo sobre corda é: "certo cortejo ou grupo carnavalesco". O autor destaca que essa definição refere ao Brasil, Rio de Janeiro (FIGUEIREDO, 1913, vol. I, p.455). Já no Dicionário do Folclore Brasileiro de Câmara Cascudo (2012), a definição de cordão é dividida em dois: uma manifestação carnavalesca, que para o autor em uma definição rápida, pode ser entendida como "grupo de foliões com roupas de fantasia, cantando e dançando, mais ou menos ritmicamente"; e uma manifestação de festa religiosa (CASCUDO, 2012, p. 225).

É pertinente considerar que embora a Bicharada do Juaba seja apresentada e considerada cordão carnavalesco, ele difere sobremaneira dos cordões carnavalescos existentes nas mais diferentes regiões do Brasil. Em Juaba, ao invés dos foliões representarem através de suas vestimentas, reis, rainhas, bobos da corte, índios, caçadores, as fantasias representam animais dos mais diferentes tamanhos. São várias araras, jacarés, cobras, macacos, jabutis, tucanos, botos e tantos outros que compõem a fauna amazônica, além de outros animais de outros continentes como girafa, urso, hipopótamo. Durante a festa do Momo, este cordão de bichos se apresenta nos trapiches das residências às margens do Rio Tocantins, ao toque de músicas próprias do grupo, em ritmos de marchinhas e também com o uso de comédias.

Segundo Arnoud (2018), nas apresentações, os animais são os protagonistas de atos performáticos, exibindo-se ao som de marchinhas de carnaval criadas por integrantes do próprio grupo, como seu Raimundo Inácio Ferreira (pai do mestre Zenóbio) e Afonso Aragão. A imagem abaixo ilustra a chegada do cordão no trapiche de uma das ilhas em Cametá. Nela, é possível observar o condutor do cordão com o estandarte do grupo, a marchinha com instrumentos de sopro e percussão e os animais, performatizados para o início do cortejo. 


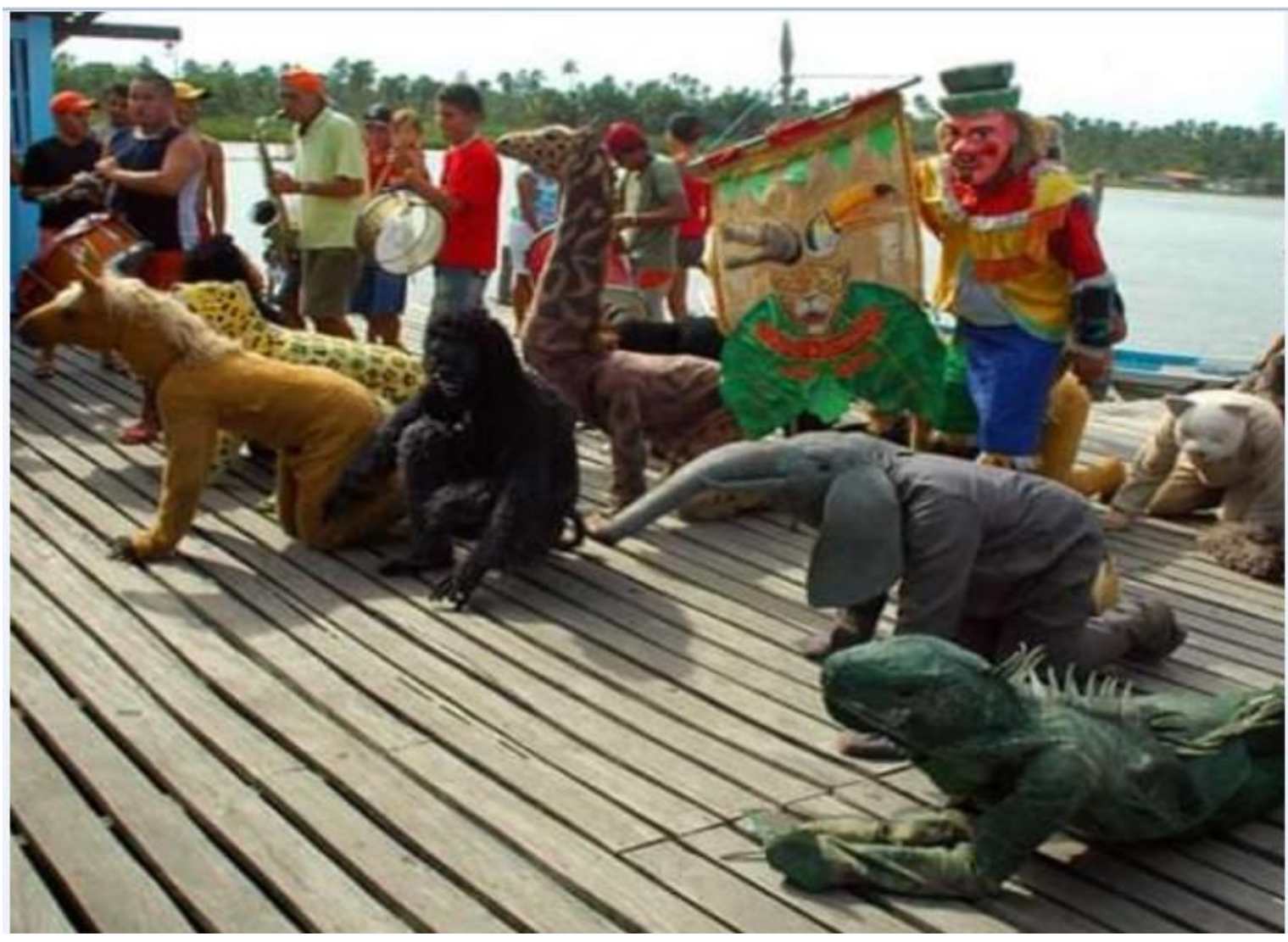

Fonte: acervo mestre Zenóbio (2010)

Durante a apresentação do cortejo, cada animal, ao ser convocado pelo domador - caracterizado de palhaço - desenvolve ato performático marcado pela composição estética de caráter espetacular. O corpo que é habitado pelo animal incorpora todo o gestual e som, gerando nos expectadores um clima de euforia, sobretudo quando conseguem identificar um animal que não pertence à fauna local. Ao término das apresentações, cada animal do cordão da bicharada deixa uma mensagem reflexiva sobre a necessidade de preservação do bio sistema, posto que:

O objetivo central do grupo está voltado para a conscientização das pessoas para a preservação da natureza e das dificuldades que os animais tem para sobreviver na floresta. (Mestre Zenóbio. Entrevista concedida em ro de março de 2org, Juaba-Pa).

Este ato performático encenado entre domador e animal é o ponto alto do cortejo do cordão da Bicharada. Mestre Zenóbio relata que:

Quando chega o momento da comédia (fala dos animais) em forma de círculo, no intervalo de uma música e outra e quando acionado pelo domador, o animal se manifesta em forma de diálogo e fala o boi e o cavalo 
contando sua trajetória de vida, depois vem o leão se apresentando como rei dos animais que por se considerar o rei da selva, deixa sua mensagem de protesto" (Mestre Zenóbio, em ıo de março de 20ı9, Juaba-Pa).

Cabe ao domador comandar o jogo entre os animais, tanto em relação aos brincantes adultos quanto às crianças. Todavia, as crianças não se apresentam sozinhas. Elas estão juntas ao adulto e, estando com o corpo alterado do mesmo animal, fazem o ato performático juntos. Mas isto não é regra. É interessante perceber que o jogo cênico contido no cordão da Bicharada, ao mesmo tempo em que permite a jocosidade, a brincadeira, também propicia aos expectadores momento reflexivo sobre a necessidade de preservação do meio ambiente, de sua flora e fauna. A seguir algumas comédias dos animais narradas no Cordão;

\section{COMÉDIA DO REI LEÃO}

Sou o rei dos animais

A selva é o meu Reinaldo

Como carne todo dia

Gosto muito de veado

Às vezes, também da zebra

E o banquete é adiado

Nas planícies africanas

Eita visão gostosa

O pôr do sol nem se fala

Que coisa maravilhosa

Eu ao lado da rainha

Que é bastante dengosa

[....] amigo palhaço

Eu já vou me retirar

A barriga ronca

Preciso me alimentar

Dê licença

Que a preguiça vou levar 
Volto para o meu reinado

E até o outro carnaval.

(Autor: Afonso Aragão)

\section{COMÉDIA DO CAVALO COM O BOI}

- Olá meu amigo boi!

- Sim senhor, amigo cavalo!

- Como é que as coisas vam?

- As coisas vam nesse ritmo desenfreado

das carradas que eu dava ontem, hoje então todas dobradas.

- E você amigo cavalo, o que tem a me dizer?

- Eu só falo em sacrifício, que tenho em meu viver com o peso em minhas costas, chicoteado, vivo a correr.

(Autor: Afonso Aragão)

\section{COMÉDIA DO BODE}

Eu sou o Bode cheiroso, grande conquistador,

Carinhoso e boa pinta, excelente reprodutor,

A cabra que se aguente tenho potência e vigor,

Já namorei a dona vaca, dona zebra, saracura,

Só não namorei a girafa porque não deu certo na altura.

Tenho I20 esposas 200 companheiras

E ainda tirei uma casquinha com as comadres fofoqueiras.

Porem agora resolvi acabar com essa loucura,

Quem anda com a mulher do outro não tem a vida segura, Cada passo que ele dar tá com o pé na sepultura.

Assim senhoras e senhores, eu já vou me retirar à cabra ta me esperando, 


\section{Eu não posso demorar \\ Um adeus Bicharada \\ E até outro evento popular.}

\section{(Autor: Afonso Aragão).}

A apresentação dos atos de comédia é carregada de teatralidade, posto que tal conceito significa qualidade daquilo que é teatral ou tem condições para ser apresentado em cena. Neste sentido, quanto mais o brincante carrega no gesto, no movimento do corpo que acentua a identificação do animal em cena, mais o expectador reage com aplausos, risadas e assobios. E é exatamente isso que a etnocenologia define como espetacularidade. Em outras palavras, a etnocenologia se estrutura como uma disciplina especializada no "estudo dos comportamentos humanos espetacularmente organizados" (PRADIER, 1995). Em seu campo investigativo, a palavra espetacularidade assume uma dimensão de primeira grandeza, por se expressar em qualidade do que é espetacular; grandiosidade; ostentação. Sua derivância vem do latim expectare - do ex- "para fora" + spectare - "olhar, observar, contemplar". Nesse sentido, a palavra espetacular está diretamente associada ao que é apresentado para ser contemplado, admirado.

Dentro do cordão da bicharada é permitida a comunicação do personagem animal e o expectador, pois por meio do jogo cênico ocorre a conscientização ao tema real - meio ambiente - causando impacto através da comédia. Neste sentido, é possível afirmar que no processo de interação entre o brincante e o expectador que acontece a íntima relação entre teatralidade e espetacularidade, já que

\footnotetext{
Teatralidade e espetacularidade - o par de categorias ideal-típicas referente à convivência em sociedade; sendo a primeira aplicada às pequenas interações rotineiras, nas quais os indivíduos agem em função do interlocutor (para o olhar do outro, como no sentido etmológico do teatro), de modo mais ou menos consciente e confuso, sem distinção clara entre 'atores e espectadores', por desempenharem, aí, todos, simultaneamente os dois 'papeis'; e a segunda aplicada às maiores interações extraordinárias, quanto coletivamente a sociedade cria fenômenos organizados para o olhar de muitos outros, que dele têm consciência clara como 'atores' ou 'espectadores' (BIÃO, 2009, p. 34).
}

A imagem a seguir captura um dos muitos momentos de interação entre brincante e expectador: 


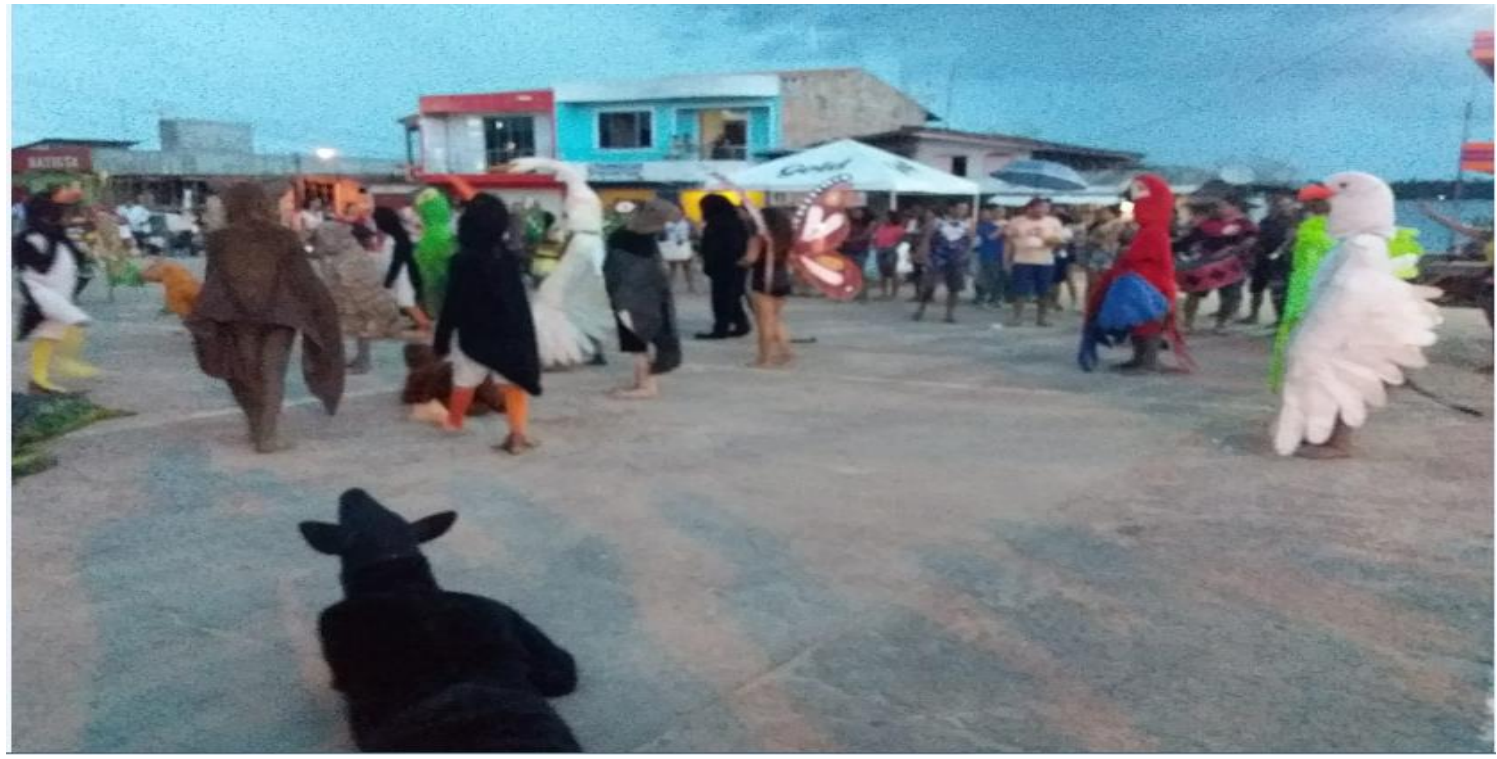

Fonte: acervo Mestre Zenóbio (2016).

A estrutura ritual do cordão da Bicharada permite, nos intervalos das apresentações dos animais, que a marchinha entre em cena para tocar suas composições musicais. As letras das músicas se constituem em chamadas reflexivas para todos os participantes do cortejo, por tratarem de temas bem atuais e caros à região Amazônica; a preservação de sua mata, sua fauna e flora. A seguir, algumas letras:

\section{NÃO ESTÁ COM NADA}

Quem faz devastação

Refrão: Não está com nada

Zombando da floresta

Fazendo queimada

Não está com nada

Quem não ara a terra

Não está com nada

Quem gosta da guerra

Não está com nada

Quem gosta de droga

Não está com nada 
Quem não reparte o pão

Não está com nada

Quem ama a natureza

Também ama a Bicharada

(Autor: Afonso Aragão)

POMBINHA

Pombinha que voa

Pombinha que voa

Não pode parar de voar

Toda a flora destruída

Toda a flora destruída

As aves não podem pousar

Não sei se é flora ou se é devastação

Não sei se é fauna ou se é poluição

Todo homem tem cabeça

Todo homem tem cabeça

Mas não tem bom coração

(Autor: Afonso Aragão)

As letras destas músicas são de domínio de grande parte dos participantes do cortejo, estejam na condição de brincante ou de expectador. Entretanto são as crianças em cena que roubam os olhares dos expectadores, posto que, à medida que cantam as músicas, vão executando coreografias bem especificas, como é o caso das meninas fantasiadas de borboleta. Neste momento, elas desenvolvem movimentos sinuosos que lembram o voo destes insetos lepidópteros.

\subsection{Mestre Zenóbio e seus bichos - processo de criação}

Quando mestre Zenóbio decidiu criar o cordão da bicharada, um grande dilema se instaurou, posto que havia necessidade de caracterização dos animais que participariam do cortejo. $\mathrm{O}$ artista relata que:

Neste momento, várias perguntas vieram na minha cabeça. Como fazer esses animais, que material podia ser utilizado? Eu já sabia que boa parte do material que fosse usado, tinha que vir da natureza. Era dela que eu tinha 
que pegar o que precisasse pra criar os animais (Mestre Zenóbio. Entrevista concedida em ro de março de 2019, Juaba-Pa).

O processo de criação dos bichos começou com esboços em desenhos da cabeça e corpo dos animais. $\mathrm{Na}$ construção do primeiro experimento da cabeça, mestre Zenóbio usou o barro como matéria prima, gerando um objeto sem forma definida. Já o segundo experimento de modelagem permitiu ao artista confeccionar a cabeça de um leão, que se tornou naquele momento, o molde para confecção de outras peças.

Conforme o relato do mestre Zenóbio, a maioria dos materiais utilizados na confecção dos animais são: sucatas, peneiros, talas de palmeiras, arame, sobras de tecidos, sacos de lona ou sarrapilheira, papel, isopor, corante feito urucum e carvão.

Para colocar sua ideia na rua, Mestre Zenóbio contou com um grupo de doze pessoas. Ele diz:

\footnotetext{
Essas doze pessoas era tudo da comunidade, meus amigos, vizinhos e até parentes. Aí, uns oito tinham habilidade de manusear o material e passaram a compor o grupo de trabalho no barracão, fazendo as cabeças e também na costura dos macacões. As outras três pessoas eram o apoio, a ajuda no corte dos tecidos, no uso das peças para ver os ajustes e até na contação das piadas pra animar o tempo, porque nosso trabalho era a noite (Mestre Zenóbio. Entrevista em ro de março de 2019. Juaba-Pa).
}

A primeira saída do Cordão da Bicharada contou com dezoito fantasias de aninais, dente eles bode, camelo, boi, jacaré, cobra, jabuti. E foi o maior alvoroço,

Quando nós saímos do barracão todos vestidos de bicho, foi surpresa geral. Todos querendo descobrir quem estava vestido daquelas fantasias, mas ninguém tirou. A gente tinha conversado antes que uma vez vestido, vestido até o fim. E é assim até hoje (Mestre Zenóbio. Entrevista em io de março de 2019. Juaba-Pa).

$\mathrm{Na}$ contemporaneidade, o Cordão da Bicharada é composto por 82 fantasias permanentes, ou seja, que foram produzidas pelo coletivo de artesãos do barracão e que saem todos os anos nos desfiles do cordão. Para além dessas 82 fantasias, o cordão também conta com outras fantasias trazidas por brincantes sazonais e geralmente são fantasias comercializadas em larga escala em armarinhos de Cametá.

\subsection{As crianças no cordão da bicharada}

Na vila de Juaba, o som do riso de crianças é uma constante. É comum observar a circulação de meninos e meninas nos espaços públicos da Vila. E essa circulação 
nunca é silenciosa, ao contrário, é sempre acompanhada de ruidosas brincadeiras infantis como "Pira se Esconde", jogo de bola, subir nas árvores. Vez ou outra é possível escutar a voz de uma mãe aborrecida, gritando ao filho ou filha para voltar "na pisada" para casa.

Em Juaba, assim como em muitas comunidades tradicionais da Amazônia paraense, as crianças participam ativamente da rotina familiar, ajudando seus pais nos diversos afazeres domésticos e também nas atividades produtivas que geram renda para a unidade doméstica, como a produção de farinha e a pesca.

Embora em muitos centros urbanos da Amazônia paraense, a divisão sexual do trabalho não seja mais um fato recorrente, o mesmo ainda não ocorre em comunidades tradicionais, como é o caso de Juaba. Um grupo considerável de famílias juabaenses executa a rotina do dia a dia pautada na divisão sexual do trabalho, cabendo às meninas atividades de cuidar da casa, de preparar a refeição da família e de cuidar dos irmãos menores. Já os meninos são envolvidos nas atividades agrícolas e de pesca, acompanhando pais, tios, irmãos mais velhos, na rotina do plantio e colheita da mandioca para a produção da farinha e outros derivados desta raiz.

A Comunidade de Juaba possui uma única escola, a Escola Municipal de Ensino Fundamental de Laranjal que atua na Educação Infantil, Educação Fundamental I e II, localizada na Beira da Várzea, Distrito de Juaba. A Escola funciona nos turnos da manhã e tarde e atende a todas as crianças da comunidade de Juaba e do seu entorno, em idade escolar.

É oportuno considerar que a funcionalidade da Escola de Juaba está intimamente relacionada com o fluxo das águas dos rios e igarapés que a circundam. Por estar localizada em uma área de várzea, no período das grandes águas, toda área que circunda o prédio escolar fica inundada, impossibilitando o acesso de funcionários, professores e alunos. Neste caso, é o processo de sazonalidade observado que determina o cronograma e ritmo de funcionamento da escola em apreço.

Quando as crianças não estão na escola ou não estão nos afazeres rotineiros, elas estão espalhadas pelas estreitas ruas de areia, em frente às casas, na praça da comunidade ou na beira dos igarapés. Durante a quadra carnavalesca, boa parte dessas crianças passam a ter um outro itinerário; o barracão do cordão da bicharada. É neste 
espaço que as crianças de Juaba aprendem a confeccionar as fantasias dos bichos de suas preferências.

No carnaval do ano de 2018 o Cordão da Bicharada contou com a participação ativa de 12 crianças, na faixa etária de 08 a 13 anos, sendo o5 do sexo feminino e o7 do sexo masculino. Durante o carnaval, em todas as apresentações do Cordão da Bicharada ocorrida nas regiões das ilhas, nas praças e ruas da cidade de Cametá, as 12 crianças integrantes do cordão estavam acompanhadas de seus responsáveis, que, na maioria das vezes, também compunham o elenco de brincantes do Cordão da Bicharada.

No barracão, as crianças são conduzidas por artesãos no manuseio dos materiais orgânicos utilizados na confecção das fantasias, como a malva e sarrapilheira e também materiais sintéticos como pelúcia, TNT, isopor e espuma. A imagem abaixo permite visualizar a presença das crianças e suas respectivas fantasias prontas no interior do barracão.

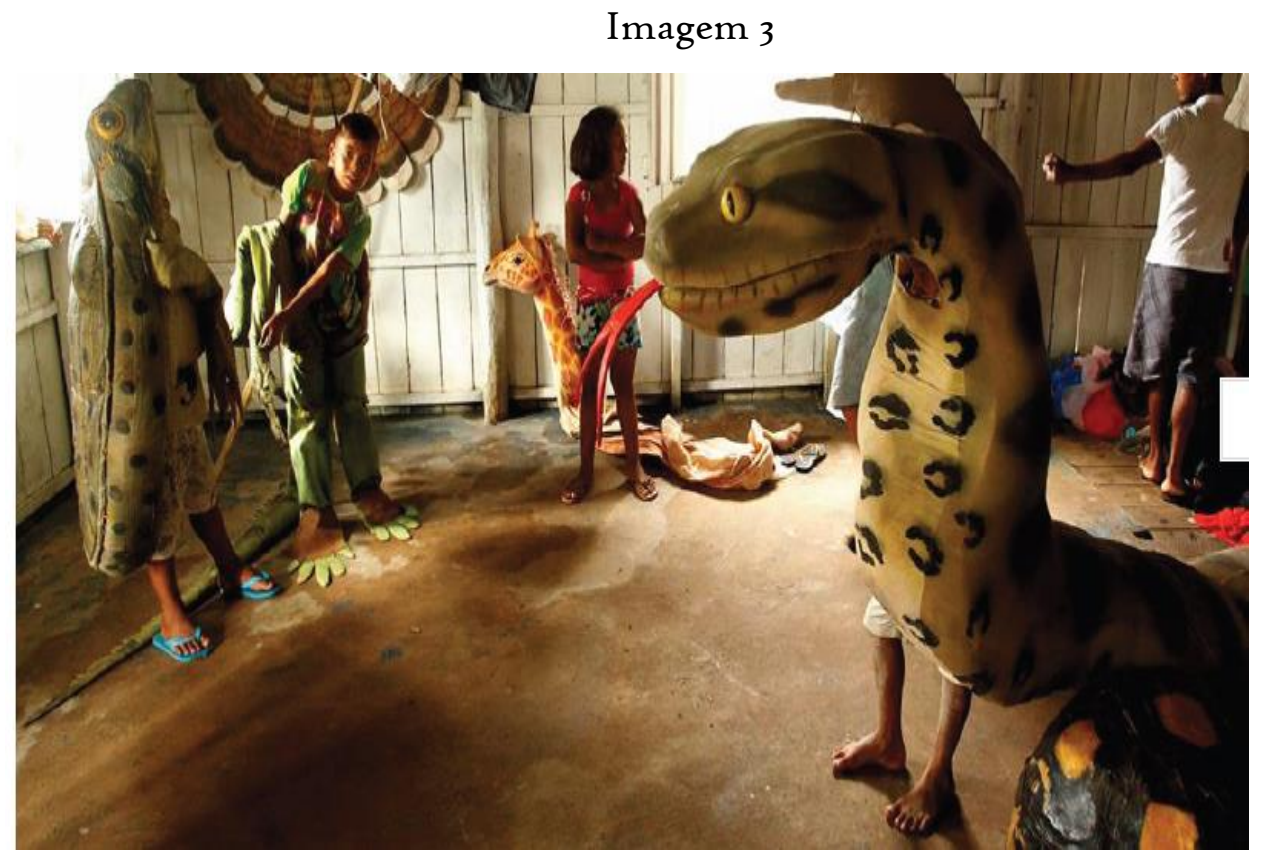

Fonte: arquivo pessoal (2018)

Mestre Zenóbio, em entrevista, comentou que quando foi idealizado o cordão da bicharada, no começo, não foi considerada a participação das crianças, posto que

[...] era como brincadeira de homem. No início, nem mulher participava. Elas acompanhavam seus maridos, namorados, mas ficavam de fora. Só depois de uns quatro anos que elas começaram a se vestir de bicho. Com as 
mulheres vieram também as crianças que sempre tinha que estar acompanhada de seu responsável. Sem isso, nem pensar em brincar no cordão. (Mestre Zenóbio, entrevista em ro de março de 2or19. Juaba-Pa).

Ainda na entrevista, Mestre Zenóbio destaca a importância da participação das crianças no Cordão da Bicharada:

É importante, muito importante, porque desde pequenas elas já aprendem a valorizar e preservar o meio ambiente, a fauna e a flora [...] e eles vão crescendo com esse cuidado de preservar, de proteger. A escola também ajuda, porque as professoras passam atividade pra eles pesquisarem sobre nosso meio ambiente (Mestre Zenóbio, entrevista em io de março de 2019. Juaba-Pa).

\subsection{Homem, criança $\mathrm{x}$ bicho - corpo alterado e metamorfoseado}

Para a Etnocenologia o corpo alterado se contitui em categoria conceitual que permite compreender o estado de afetação pelo qual passa o corpo que está envolvido em eventos rituais, os quais se tornam campo investigativo.

O Cordão da Bicharada por estar vinculado ao evento ritual carnaval, permite afirmar que a categoria corpo alterado está presente no ato performático dos brincantes durante o cortejo do cordão. O estado de corpo alterado pode ser observado em três momentos do cortejo; concentração, apresentação, dispersão. $O$ momento da concentração, antecede a apresentação. É quando o brincante veste a fantasia e aquece o corpo com movimentos rítmicos capazes de acionar o estado de corpo do animal vestido. Neste momento é permitida a ingestão de bebidas alcoólicas, dando ao brincante uma espécie de suporte psicológico para suportar o peso e a alta temperatura da fantasia. O depoimento a seguir é bastante ilustrativo quando narra que

[...] a fantasia é pesada. Essa parte de cabeça que pesa porque é feita a partir de uma armação de arame para dar sustentação. A roupa da fantasia também pesa. Essa aqui é do macaco. A gente primeiro veste o corpo, e antes de colocar a cabeça, vai bem umas geladas pra gente aguentar tudo, porque, depois que veste só tiramos a roupa quando tudo termina (Depoimento de Carlos Augusto da Silva, brincante do Cordão da Bicharada, em ıo de março de 2019, Juaba-Pa).

$\mathrm{Na}$ apresentação, o corpo do animal fantasiado assume a cena. $\mathrm{O}$ som e o movimento corpóreo feito pelo brincante é do jacaré, jabuti, pavão, cobra, arara, tucano, boto, macaco, e tantos outros animais da fauna amazônica ou de outros lugares, como é o caso do camelo, girafa, leão. Neste momento, o brincante deixa de ser ele para dar passagem ao animal performatizado. Durante a apresentação, que dura em 
média quatro horas, o brincante adulto não poderá tirar nenhuma parte da fantasia, também não poderá atender a chamada de seu nome, muito menos parar de executar os movimentos e sons de seu animal. Todavia, esta exigência não atinge as crianças brincantes. Elas, as crianças, embora consigam executar atos performativos de seus animais, podem interrompê-los para descansar e até mesmo brincar. É muito comum, durante o cortejo do Cordão da Bicharada, observar araras, tucanos, macacos brincando de "corre corre" ou simplesmente sentados no meio fio das ruas de Cametá, onde ocorre a folia de carnaval. A imagem a seguir ilustra os corpos alterados no instante da apresentação:

\section{Imagem 4}

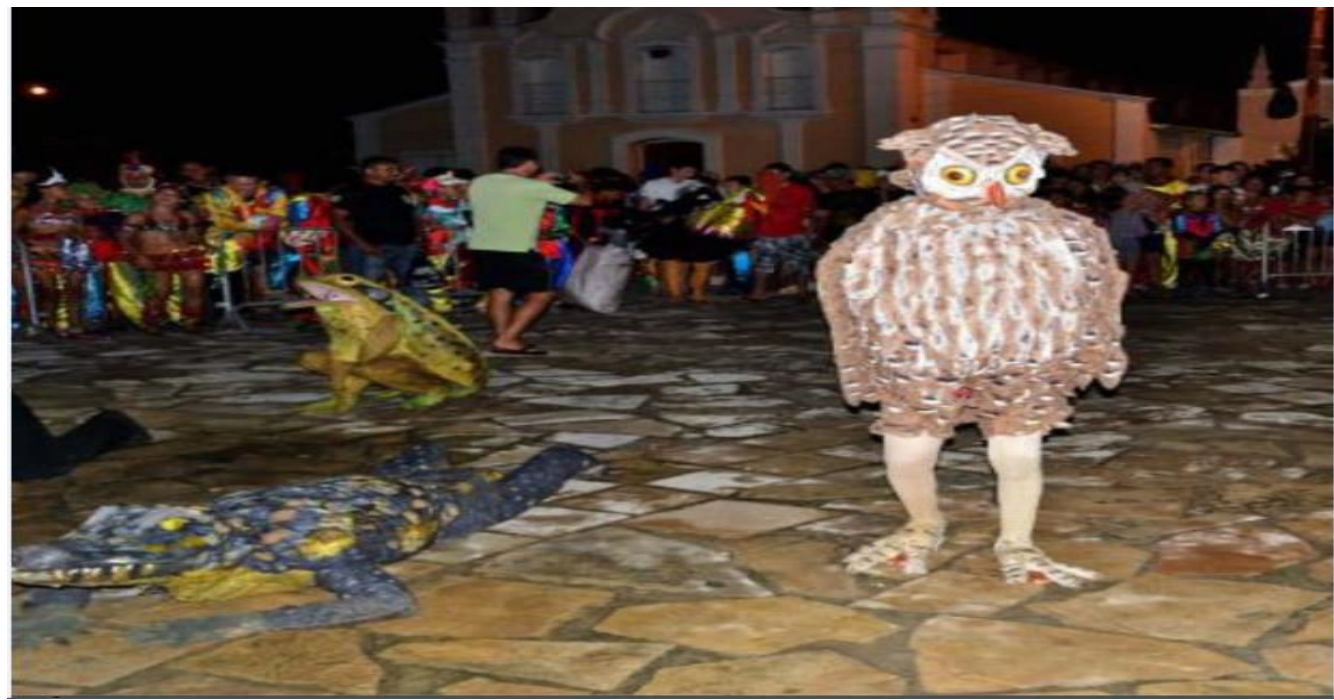

Fonte: arquivo pessoal (2018).

Para a brincante Cintia, o corpo performatizado do animal no momento da apresentação é grandioso, porque

Ao me caracterizar de tucano, percebo que naquele momento, é como se fosse real. Durante as apresentações é como se meu corpo se transformasse, o eu mulher deixo de existir, me sinto livre e leve, como em um passe de mágica não sinto calor nem sede". (Depoimento da brincante Cintia Dias, em I2 de março de 2019, Juaba-Pa).

É importante destacar que embora não ocorra maior cobrança com as crianças no ato da apresentação, o próprio envolvimento das mesmas no Cordão da Bicharada é pensado como muito importante, porque instaura no grupo o sentido de continuidade. Sobre esta questão, Mestre Zenóbio diz:

No começo eu não concordei com a ideia das crianças participarem. Achava que não era lugar para elas, que podiam até se machucar. Mas com o passar 
do tempo, fui vendo que era muito importante, porque, se queremos que o cordão tenha vida longa, isso só será possível se as crianças estiverem junto com a gente, porque elas vão, desde pequenas entendendo a importância de tudo isso (Depoimento de Mestre Zenóbio, em ro de março de 2019. Juaba$\mathrm{Pa})$.

Embora as fantasias destinadas às crianças sejam de animais de pequeno porte, como araras, urubus, peru, galo, cobra, boto, suas fantasias são adaptadas ao corpo infantil e as crianças que passam a integrar o cordão são escolhidas, principalmente pelo porte físico e habilidade em fazer os movimentos dos animais representados.

$\mathrm{Na}$ maioria das vezes, o corpo da criança vai se metamorfoseando no ato da apresentação, que para ela é mais um instante de brincadeira, de alegria e divertimento. Assim, é no aqui e agora que a criança entra no jogo cênico, sobretudo no movimento de interação com o expectador que assiste, maravilhado, as performances. Também este momento as crianças são orientadas por voluntários que acompanham as apresentações e a dinâmica entre as próprias crianças no momento da caracterização que acontece no coletivo, como deixa claro o depoimento a seguir:

Quando eu me disponibilizei a fazer parte como voluntário do grupo a Bicharada, já conhecia o comportamento dos animais representados conhecia seus gestos, movimentos e sons esses são fatores primordiais para fazer parte do grupo, é uma atenção redobrada para orientar as crianças durante o percurso" (Depoimento de Kennedy Barroso, em 2i de março de 2019, Juaba-Pa).

Já o momento da dispersão, como o próprio nome diz, é o encerramento da apresentação, quando o cordão da bicharada está fora do circuito do evento. É nesta etapa que os corpos dos brincantes voltam à cena. $\mathrm{Na}$ maioria das vezes estes corpos saem da condição de brincantes para se tornarem expectadores, quando assistem à exibição de outros blocos de carnaval.

\section{CONSIDERAÇÕES FINAIS}

O Cordão da Bicharada de Juaba já é considerado pelos moradores da localidade como parte indissociável de sua tradição cultural e também, da cidade de Cametá, uma vez que Juaba pertence a macroregião deste município paraense.

A exemplo do que acontece com o "Carnaval das àguas" de Cametá que colocou este município no mapa de turismo, o Cordão da Bicharada também tirou Juaba da 
invisibilidade regional quando este cordão foi (e ainda é) tema de várias reportagens jornalísticas publicadas nos jornais da cidade de Belém. Essa divulgação, cada vez mais recorrente do carnaval de Juaba tem oportunizado a instauração do sentimento de pertença junto aos nascidos na comunidade em apreço que cada vez mais, tentam repassar essa valoração do lugar de origem e da cultura local aos seus descendentes. Fato inconteste é a crescente participação das crianças nas apresentações do cordão da Bicharada. Se antes essa participação era considerada preocupação por parte do idealizador do cordão, hoje ela é estimulada, não só por ele, mas por familiares e professores desses brincantes mirins.

O recorte analítico realizado na construção deste artigo encontrou amparo na etnocenologia, concentrando o olhar investigativo nas categorias conceituais teatralidade e espetacularidade, posto que, a luz da etnocenologia, tanto teatralidade como espetacularidade se constituem em jogos cênicos presentes tanto no tempo ordinário quanto no extraordinário, ou seja,

[...]São os jogos cotidianos e os rituais extraordinários que constituem essas articulações: teatralidade e espetacularidade para simplificar, exageremos: as características do teatral são o que se referem ao espaço ordenado em função do olhar (do grego theatron); expetacular é o que caracteriza o que é olhado ( do latim espectare) (Bião, 1990. p.162).

Neste sentido, o processo de construção deste artigo privilegiou a compreensão do cordão da bicharada como evento ritual no campo do extra cotidiano e seu cortejo sendo marcado por vários sentimentos, expressos na fisionomia daqueles que acompanham o trajeto do cordão na condição de expectadores. $O$ jogo cênico do cordão da Bicharada se desenvolve através da presença do domador - palhaço X animal. Nas cenas, cabe ao domador apresentar o animal, que por sua vez, se dirige ao centro para iniciar seu ato performático em um primeiro plano, narrando a história de vida, em forma de rima, do animal que se apresenta, para, na sequência, executar os movimentos e sons do animal.

$\mathrm{Na}$ contemporaneidade o cordão da Bicharada está tão incorporado à cultura local de Juaba e da cidade de Cametá, que comumente é acionado como tema gerador de diferentes disciplinas ministradas nas séries da Escola de Ensino Fundamental de Juaba. Aos recorrentes debates sobre meio ambiente e preservação da natureza que o 
cordão da Bicharada tem provocado no cotidiano da comunidade e também no espaço da sala de aula, soma-se a inculcação da noção de pertencimento. No tempo presente, as crianças de Juaba sentem orgulho de pertencer à comunidade e de possuir o cordão da Bicharada, que, em certa medida, permitiu colocar a todos e, em particular, seus modos de viver e brincar o carnaval nos circuitos das festas e festividades que acontecem nas várias regiões brasileiras durante a quadra carnavalesca.

\section{REFERÊNCIAS}

BIÃO, Armindo. Etnocenologia e a Cena Baiana: textos reunidos. Salvador: P\&G Gráfica e Editora, 2009.

BRIGIDA, Miguel Santa. A etnocenologia na Amazônia. trajetos-projetos-objetosafetos. Repertório, Salvador, no 25, p.13-23, 2015.

CASCUDO, Luís da Câmara. Dicionário do Folclore Brasileiro. Editora Global, 2012.

FIGUEIREDO, Candido de. Novo Diccionário da Língua Portuguêsa. Lisboa: Editora Tavares, vol. II, i889.

FIGUEIREDO, Candido de. Novo Dicionnário da Língua Portuguesa. Lisboa: Livraria Clássica Editora, vol. II, I913.

GOMES, F. S. "No labirinto dos rios, furos e igarapés": camponeses negros, memória e pós-emancipação na Amazônia, c. XIX-XX. In: História Unisinos, vol. ıo, no 3, p. 28I-292, 2006.

HOUAISS, Antônio; VILLAR, Mauro de Salles (Org.). Dicionário Houaiss da Língua Portuguesa. Rio de janeiro: Objetiva, 2001.

PRADIER, Jean-Marie, Etnocenologia. In: GREINER, Christine e BIAO, Armindo. (org.). Etnocenologia: textos selecionados. São Paulo: Annablume,rig99.

ROY, Wagner. A invenção da Cultura. 2017. Rio de Janeiro. p. 384.

SOUSA, Raimundo Valdomiro de. Campesinato na Amazônia: da subordinação à luta pelo poder. Belém: NAEA, 2002.

TAVARES. Luciana P. de O. A Definição do Rural e do Urbano e suas Influências na Implantação de Políticas Públicas: UM ESTUDO DE CASO EM DUAS LOCALIDADES NA CIDADE DE CAMETÁ - PA. Dissertação de Mestrado. Belém- PA. 2009. 